\title{
Cytotoxicity and Apoptotic Inducibility of Vitex agnus-castus Fruit Extract in Cultured Human Normal and Cancer Cells and Effect on Growth
}

\author{
Kunio Ohyama, ${ }^{* a}$ Takenori Akaike, ${ }^{a}$ Chieko Hirobe, ${ }^{b}$ and Toshio Yamakawa ${ }^{a}$ \\ ${ }^{a}$ Department of Biochemistry, Faculty of Pharmacy, Tokyo University of Pharmacy \& Life Science; 1432-1 Horinouchi, \\ Hachioji, Tokyo 192-0355, Japan: ${ }^{b}$ Department of Cultural History, Seisen University, Tokyo; 3-16-21 Higashigotanda, \\ Shinagawa-ku, Tokyo 141-0022, Japan. Received July 8, 2002; accepted October 1, 2002
}

\begin{abstract}
A crude extract was prepared with ethanol from dried ripened Vitex agnus-castus fruits growing in Israel (Vitex extract). Cytotoxicity of the extract against human uterine cervical canal fibroblast (HCF), human embryo fibroblast (HE-21), ovarian cancer (MCF-7), cervical carcinoma (SKG-3a), breast carcinoma (SKOV-3), gastric signet ring carcinoma (KATO-III), colon carcinoma (COLO 201), and small cell lung carcinoma (Lu-134-A-H) cells was examined. After culture for $24 \mathrm{~h}$ (logarithmic growth phase) or $72 \mathrm{~h}$ (stationary growth phase), the cells were treated with various concentrations of Vitex extract. In both growth phases, higher growth activity of cells and more cytotoxic activity of Vitex extract were seen. The cytotoxic activity against stationary growth-phase cells was less than that against logarithmic growth-phase cells. DNA fragmentation of Vitex extract-treated cells was seen in SKOV-3, KATO-III, COLO 201, and Lu-134-A-H cells. The DNA fragmentation in Vitex extracttreated KATO-III cells was inhibited by the presence of the antioxidative reagent pyrrolidine dithiocarbamate or $\mathrm{N}$-acetyl-L-cysteine (NAC). Western blotting analysis showed that in Vitex extract-treated KATO-III cells, the presence of NAC also inhibited the expression of heme oxygenase-1 and the active forms of caspases-3, -8 and $\mathbf{- 9}$. It is concluded that the cytotoxic activity of Vitex extract may be attributed to the effect on cell growth, that cell death occurs through apoptosis, and that this apoptotic cell death may be attributed to increased intracellular oxidation by Vitex extract treatment.
\end{abstract}

Key words Vitex agnus-castus; cytotoxic activity; apoptosis; growth rate; antitumor effect

Vitex agnus-castus is a shrub belonging to the Verbenaceae family, which grows naturally and is common in the Middle East and southern Europe. Its ripened fruits have been used as a folk medicine for a long time for alleviation and/or improvement of symptoms from obstetric and gynecological diseases. Hobbs, in "Vitex: The Women's Herb", described Vitex as an effective remedy for emmeniopathy, including amenorrhea, oligomenorrhea, and menorrhagia, and that due to estrogen hypersecretion before menstruation in premenstrual tension, long-term use of $V$. agnus-castus reduced those symptoms and prevented relapse of the disease. ${ }^{1)}$ It also appears that the function of the corpus luteum in corpus luteum deficiency syndrome improved with V. agnus-castus due to the crinogenic effect of luteinizing hormones.

Hirobe et al. reported that an antitumor effect results from the extract of ripened Israeli-grown $V$. agnus-castus fruits (Vitex extract) on the Chinese hamster lung carcinoma cells line V-79, and that Vitex extract has high antitumor activity. ${ }^{2}$ Furthermore, analysis of the components of Vitex extract showed four types of new flavonoid compound and four known flavonoids. ${ }^{3)}$ We investigated the cytotoxicity of Vitex extract against a normal human cell line, human uterine cervical fibroblasts (HCF), and the cancer cell lines breast carcinoma (MCF-7) and ovarian cancer (SKOV 3). Using these three cell lines, we found that the cytotoxic activity of Vitex extract may be attributed to the growth activity of the respective cell, and demonstrated the possibility that the cytotoxicity is related to the cell cycle stage. ${ }^{4}$

To investigate the antitumor effects of Vitex extract in more detail, we examined the cytotoxicity of Vitex extract against two noncancerous and six cancerous human cell lines. The cytotoxic activity of Vitex extract was confirmed to depend on the growth rate of the cells, the cytotoxic cell death of cells with relatively low growth activity occurs through apoptosis, and apoptotic cell death results from an increase in intracellular oxidation.

\section{MATERIALS AND METHODS}

Cells and Media The breast carcinoma (MCF-7) ${ }^{5)}$ and gastric signet ring carcinoma (KATO III) ${ }^{6}$ cell lines were described previously. Cervical carcinoma (SKG-3a), colon carcinoma (COLO 201), and small cell lung carcinoma (Lu134-A-H) cell lines were provided by the JCRB Cell Bank (Tokyo, Japan). The ovarian cancer (SK-OV-3) cell line was provided by the American Type Culture Collection (Rockville, MD, U.S.A.). Fetal fibroblasts (HE-21) were obtained from the Research Institute for Functional Peptides (Yamagata, Japan). HCF was prepared as previously described. ${ }^{7)}$ Pyrrolidine dithiocarbamate (PDTC) and $\mathrm{N}$-acetylL-cysteine (NAC) were purchased from Dojindo Laboratories and Wako Pure Chemical Industries, respectively.

Preparing Ethanol Extract from Dried Ripened $V$. agnus-castus Fruits Dried, ripened, Israeli-grown V. agnuscastus fruits were triturated, and a crude extract was prepared from the triturate $(1 \mathrm{~g})$ with ethanol $(10 \mathrm{ml})$ under reflux for $2 \mathrm{~h}$. After the extract was cooled, filtrated, and evaporated, it was dried in a vacuum desiccator. The ethanol extract was referred to as the Vitex extract, and its yield was $0.08-0.1 \mathrm{~g}$ from $1 \mathrm{~g}$ of dried fruit.

Treatment of Cultured Cells with Vitex Extract and Cell Viability Assays Two different methods were used to investigate the cytotoxicity of Vitex extract. To investigate the cytotoxic activity of Vitex extract against logarithmic growth-phase cells, $0.1 \mathrm{ml}$ of cell suspension was inoculated into 96-well microculture plates at 7500, 10000, 25000, 
50000 , and 100000 cells $/ \mathrm{ml}$ in the respective culture media. Vitex extract was dissolved in dimethyl sulfoxide (DMSO) $50 \mathrm{mg} / \mathrm{ml}$ and diluted at the appropriate concentrations with the respective cultivation medium. After $24 \mathrm{~h}$ cultivation, $0.1 \mathrm{ml}$ of each Vitex extract solution was added at a final concentration of $5,10,30,50,70,90$, or $100 \mu \mathrm{g} / \mathrm{ml}$ to quadruple culture wells. After these cultures were incubated for $48 \mathrm{~h}$, the cell viability was confirmed by XTT dye-reduction assay according to the method described previously. ${ }^{8}$ For the control assay, cells were treated with the respective medium containing $0.05 \%$ DMSO without Vitex extract. To investigate the cytotoxicity of Vitex extract against stationary-phase cells, each cell suspension was prepared at $1 \times 10^{6}$ cells $/ \mathrm{ml}$ of the appropriate medium, and $0.1 \mathrm{ml}$ of each suspension was inoculated into a 96-well microculture plate. After these cells were cultivated for $72 \mathrm{~h}, 0.1 \mathrm{ml}$ of Vitex extract solution was added to each well at a final concentration of $1,5,10,30,50,70,90$ or $100 \mu \mathrm{g} / \mathrm{ml}$ for triplicate assay. After these cultures were incubated for $48 \mathrm{~h}$, the XTT dye-reduction assay was performed according to the method described above.

Preparation of DNA and Analysis by Agarose Gel Electrophoresis DNA preparation and agarose gel electrophoresis were carried out according to the method previously reported. ${ }^{9)}$ Extracted DNA was dispersed in a suitable volume of lysis buffer, and about $20 \mu \mathrm{g} / 20 \mu \mathrm{l}$ of DNA was then loaded onto a $2 \%$ agarose (Agarose X, Nippon Gene, Tokyo, Japan) gel electrophoresis column. Gels were stained with ethidium bromide (Sigma Chemical Co.) and viewed under UV light.

Western Blotting Analysis For Western blotting analysis, cell pellets $\left(1-2 \times 10^{6}\right.$ cells $)$ were dissolved in $100 \mu \mathrm{l}$ of Laemmli buffer. ${ }^{10}$ ) The dissolved tissue homogenate was boiled in a water bath for $5 \mathrm{~min}$, and then centrifuged at $13000 \times \boldsymbol{g}$ for $15 \mathrm{~min}$ at $4{ }^{\circ} \mathrm{C}$. The protein concentration of the supernatant was determined according to Bradford's method using the protein assay dye reagent (Bio-Rad Laboratories Ltd.) and bovine serum albumin as a standard. ${ }^{11)}$ Sodium dodecyl sulfate-polyacrylamide gel electrophoresis (SDS-PAGE) was performed with 12\% SDS-polyacrylamide gel under reducing conditions. ${ }^{12)}$ Protein bands on the gel were transferred into a nitrocellulose seat with Semi-dry Transfer Cells (Bio-Rad) at $30 \mathrm{~V}$ for $16 \mathrm{~h}$ at $4{ }^{\circ} \mathrm{C}$ according to the Bio-Rad instruction manual. The nitrocellulose blots were blocked in 5\% skim milk dissolved in phosphate buffered saline (PBS) containing 0.05\% Tween (PBS-Tween) for $1 \mathrm{~h}$ at room temperature and probed with an appropriate antibody (the first-step antibody) solution according to the method in the recommendation from the supplier. Anti-heme oxygenase (HO)-1, and anti-caspase (Cas)-3 antibodies were purchased from StressGen Biotechnologies Corp. (Canada), and anti-Cas-8 and -9 antibodies were purchased from BD Biosciences (U.S.A.). For staining the seat, an ECL Western blotting analysis system kit (Amersham Pharmacia Biotech) containing a horseradish peroxidase-conjugated antibody specific for the first-step antibody as a secondary antibody was used according to the instruction manual. A Luminoimage analyzer (LAS1000 plus, Fuji Film, Japan) was used for detection of specific protein bands on the nitrocellulose seat.

\section{RESULTS}

Cytotoxic Effects of Vitex Extract Correlate with Cell Growth Activity The relationship between cell growth rate and relative growth rate is shown in Table 1. These cell lines were separated into two groups based on their growth rate. Growth rates of HCF, HE-21, MCF-7, SKG-3a, and SKOV-3 cells were higher than those of KATO-III, COLO 201, and Lu-134-A-H cells. Vitex extract did not have cytotoxic activity against HE-21 cells. In both cell groups, higher initial cell density, higher formazan formation (as the growth rate) after $72 \mathrm{~h}$ cultivation, and except for HE-21, a higher growth rate indicated more effective inhibition of cell growth (higher cytotoxic activity of Vitex extract).

As shown in Fig. 1, the correlation coefficient of growth rate and relative growth rate for each Vitex extract concentration was calculated. In both the higher growth rate cell group (HCF, MCF-7, SKG-3a, and SKOV-3) (Fig. 1A) and the lower growth rate cell group (COLO 201, Lu-134-A-H, and KATO-III) (Fig. 1B), there was a significant correlation between the cytotoxic effect of Vitex extract and the cell growth activity, depending on the Vitex extract concentration. These results also suggest that the cytotoxicity of Vitex extract against these cells is also closely related to their growth activity.

Cytotoxic Effects of Vitex Extract at the Stationary Phase of Growth Next, we investigated the cytotoxic effects of Vitex extract against stationary-phase cells. As shown in Fig. 2, the viability of HE-21 cells was not inhibited at any Vitex extract concentration. While the growth of every cell line except HE-21 was repressed at higher concentrations of Vitex extract (more than $70 \mu \mathrm{g} / \mathrm{ml}$ ), cell growth was suppressed to varying degrees revealed at lower concentrations $(10-70 \mu \mathrm{g} / \mathrm{ml})$. The most effective suppression was seen in KATO-III cells at $100 \mu \mathrm{g} / \mathrm{ml}$ of Vitex extract. Viability decreased to $48 \%$ compared with the corresponding control group (untreated reference cells). While inhibition of cell viability was seen in every cell line except HE-21 cells, dosedependent inhibition depending on the Vitex extract-dose was not demonstrated.

Possibility of Apoptotic Cell Death The cells were cultured for $48 \mathrm{~h}$ and then treated with various concentrations of Vitex extract for $48 \mathrm{~h}$. Fragmented DNA extracted from the cells was analyzed by agarose gel electrophoresis. As shown in Figs. 3A-D, HCF, HE-21, MCF-7, and SKG-3a cell DNA did not show any fragmentation on the gel, while SKOV-3, KATO-III, COLO 201, and Lu-134-A-H cell DNA was fragmented (Figs. 3E-H). The fragmentation level in each cell line was dependent on the concentration of Vitex extract.

Intracellular Oxidative Stress May Result in Apoptotic Cell Death We examined the effect of antioxidative reagents on DNA fragmentation in Vitex extract-treated KATO-III cells. As shown in Figs. 4A and B, DNA fragmentation due to Vitex extract treatment was significantly decreased in the presence of $0.05 \mathrm{~mm}$ PDTC or $20 \mathrm{~mm}$ NAC. As shown in Fig. 4C, the fragmentation rates decreased from $68 \%$ to $26 \%$ and $24 \%$ with PDTC and NAC, respectively. These rates were almost the same as that in control cells. Furthermore, the viability of Vitex extract-treated KATO-III cells in the presence of $20 \mathrm{~mm}$ NAC was almost the same as that of control cells using the Trypanblue dye-exclusion 
Table 1. Cytotoxic Activity of Vitex Extract against Human Cultured Cells in the Logarithmic Growth Phase

\begin{tabular}{|c|c|c|c|c|c|c|c|c|c|}
\hline Cell & $\begin{array}{c}\text { Number of } \\
\text { cells (cells/ml) }\end{array}$ & $\begin{array}{l}\text { Vitex conc. } \\
\qquad(\mu \mathrm{g} / \mathrm{ml})\end{array}$ & $\begin{array}{l}\text { Growth } \\
\text { rate }\end{array}$ & $\begin{array}{l}\text { Relative } \\
\text { growth rate }\end{array}$ & Cell & $\begin{array}{c}\text { Number of } \\
\text { cells (cells/ml) }\end{array}$ & $\begin{array}{l}\text { Vitex conc. } \\
\qquad(\mu \mathrm{g} / \mathrm{ml})\end{array}$ & $\begin{array}{l}\text { Growth } \\
\text { rate }\end{array}$ & $\begin{array}{l}\text { Relative } \\
\text { growth rate }\end{array}$ \\
\hline \multirow[t]{40}{*}{$\mathrm{HCF}$} & \multirow[t]{8}{*}{7500} & 0 & \multirow[t]{8}{*}{3.60} & 1.00 & \multirow[t]{40}{*}{ HE-21 } & \multirow[t]{8}{*}{7500} & 0 & \multirow[t]{8}{*}{6.20} & 1.00 \\
\hline & & 5 & & 1.00 & & & 5 & & 1.52 \\
\hline & & 10 & & 0.93 & & & 10 & & 1.51 \\
\hline & & 30 & & 0.72 & & & 30 & & 1.49 \\
\hline & & 50 & & 0.25 & & & 50 & & 1.48 \\
\hline & & 70 & & 0.15 & & & 70 & & 1.43 \\
\hline & & 90 & & 0.07 & & & 90 & & 1.03 \\
\hline & & 100 & & 0.07 & & & 100 & & 0.62 \\
\hline & \multirow[t]{8}{*}{10000} & 0 & \multirow[t]{8}{*}{2.80} & 1.00 & & \multirow[t]{8}{*}{10000} & 0 & \multirow[t]{8}{*}{3.84} & 1.00 \\
\hline & & 5 & & 1.00 & & & 5 & & 1.60 \\
\hline & & 10 & & 0.89 & & & 10 & & 1.57 \\
\hline & & 30 & & 0.78 & & & 30 & & 1.58 \\
\hline & & 50 & & 0.27 & & & 50 & & 1.54 \\
\hline & & 70 & & 0.11 & & & 70 & & 1.41 \\
\hline & & 90 & & 0.06 & & & 90 & & 1.30 \\
\hline & & 100 & & 0.06 & & & 100 & & 0.62 \\
\hline & 25000 & 0 & 2.44 & 1.00 & & 25000 & 0 & 3.17 & 1.00 \\
\hline & & 5 & & 1.02 & & & 5 & & 1.45 \\
\hline & & 10 & & 0.93 & & & 10 & & 1.38 \\
\hline & & 30 & & 0.95 & & & 30 & & 1.41 \\
\hline & & 50 & & 0.62 & & & 50 & & 1.39 \\
\hline & & 70 & & 0.14 & & & 70 & & 1.30 \\
\hline & & 90 & & 0.07 & & & 90 & & 1.18 \\
\hline & & 100 & & 0.08 & & & 100 & & 0.41 \\
\hline & 50000 & 0 & 1.51 & 1.00 & & 50000 & 0 & 1.53 & 1.00 \\
\hline & & 5 & & 0.86 & & & 5 & & 1.11 \\
\hline & & 10 & & 0.84 & & & 10 & & 0.95 \\
\hline & & 30 & & 0.81 & & & 30 & & 0.98 \\
\hline & & 50 & & 0.83 & & & 50 & & 0.98 \\
\hline & & 70 & & 0.73 & & & 70 & & 0.96 \\
\hline & & 90 & & 0.41 & & & 90 & & 0.96 \\
\hline & & 100 & & 0.27 & & & 100 & & 1.14 \\
\hline & 100000 & 0 & 1.17 & 1.00 & & 100000 & 0 & 1.05 & 1.00 \\
\hline & & 5 & & 0.97 & & & 5 & & 1.30 \\
\hline & & 10 & & 0.93 & & & 10 & & 1.19 \\
\hline & & 30 & & 0.91 & & & 30 & & 1.14 \\
\hline & & 50 & & 0.92 & & & 50 & & 1.15 \\
\hline & & 70 & & 0.87 & & & 70 & & 1.16 \\
\hline & & 90 & & 0.58 & & & 90 & & 1.22 \\
\hline & & 100 & & 0.26 & & & 100 & & 1.06 \\
\hline MCF-7 & 7500 & 0 & 9.23 & 1.00 & SKG-3a & 7500 & 0 & 4.58 & 1.00 \\
\hline & & 5 & & 1.09 & & & 5 & & 1.20 \\
\hline & & 10 & & 0.99 & & & 10 & & 1.29 \\
\hline & & 30 & & 0.97 & & & 30 & & 1.01 \\
\hline & & 50 & & 0.85 & & & 50 & & 1.11 \\
\hline & & 70 & & 0.68 & & & 70 & & 0.86 \\
\hline & & 90 & & 0.61 & & & 90 & & 0.64 \\
\hline & & 100 & & 0.32 & & & 100 & & 0.20 \\
\hline & 10000 & 0 & 7.47 & 1.00 & & 10000 & 0 & 5.30 & 1.00 \\
\hline & & 5 & & 1.03 & & & 5 & & 1.18 \\
\hline & & 10 & & 0.96 & & & 10 & & 1.10 \\
\hline & & 30 & & 0.97 & & & 30 & & 1.03 \\
\hline & & 50 & & 0.78 & & & 50 & & 0.96 \\
\hline & & 70 & & 0.77 & & & 70 & & 0.75 \\
\hline & & 90 & & 0.67 & & & 90 & & 0.51 \\
\hline & & 100 & & 0.34 & & & 100 & & 0.11 \\
\hline & 25000 & 0 & 2.95 & 1.00 & & 25000 & 0 & 1.71 & 1.00 \\
\hline & & 5 & & 0.94 & & & 5 & & 1.12 \\
\hline & & 10 & & 0.88 & & & 10 & & 1.18 \\
\hline & & 30 & & 0.87 & & & 30 & & 1.22 \\
\hline & & 50 & & 0.72 & & & 50 & & 1.04 \\
\hline & & 70 & & 0.81 & & & 70 & & 0.98 \\
\hline & & 90 & & 0.76 & & & 90 & & 0.71 \\
\hline & & 100 & & 0.42 & & & 100 & & 0.30 \\
\hline & 50000 & 0 & 1.73 & 1.00 & & 50000 & 0 & 1.75 & 1.00 \\
\hline & & 5 & & 1.00 & & & 5 & & 1.01 \\
\hline & & 10 & & 0.95 & & & 10 & & 1.08 \\
\hline & & 30 & & 0.95 & & & 30 & & 1.11 \\
\hline
\end{tabular}


Table 1. (Continued)

\begin{tabular}{|c|c|c|c|c|c|c|c|c|c|}
\hline Cell & $\begin{array}{c}\text { Number of } \\
\text { cells (cells/ml) }\end{array}$ & $\begin{array}{l}\text { Vitex conc. } \\
\qquad(\mu \mathrm{g} / \mathrm{ml})\end{array}$ & $\begin{array}{l}\text { Growth } \\
\text { rate }\end{array}$ & $\begin{array}{l}\text { Relative } \\
\text { growth rate }\end{array}$ & Cell & $\begin{array}{c}\text { Number of } \\
\text { cells (cells/ml) }\end{array}$ & $\begin{array}{l}\text { Vitex conc. } \\
(\mu \mathrm{g} / \mathrm{ml})\end{array}$ & $\begin{array}{l}\text { Growth } \\
\text { rate }\end{array}$ & $\begin{array}{l}\text { Relative } \\
\text { growth rate }\end{array}$ \\
\hline & & 50 & & 0.88 & & & 50 & & 1.14 \\
\hline & & 70 & & 0.87 & & & 70 & & 1.06 \\
\hline & & 90 & & 0.87 & & & 90 & & 0.89 \\
\hline & & 100 & & 0.88 & & & 100 & & 0.60 \\
\hline & 100000 & 0 & 1.31 & 1.00 & & 100000 & 0 & 1.11 & 1.00 \\
\hline & & 5 & & 0.98 & & & 5 & & 1.06 \\
\hline & & 10 & & 1.01 & & & 10 & & 0.95 \\
\hline & & 30 & & 0.97 & & & 30 & & 0.95 \\
\hline & & 50 & & 0.96 & & & 50 & & 0.88 \\
\hline & & 70 & & 1.01 & & & 70 & & 0.98 \\
\hline & & 90 & & 0.94 & & & 90 & & 0.83 \\
\hline & & 100 & & 0.90 & & & 100 & & 0.67 \\
\hline \multirow{40}{*}{ SKOV-3 } & 7500 & 0 & 6.43 & 1.00 & KATO-III & 7500 & 0 & 1.95 & 1.00 \\
\hline & & 5 & & 1.00 & & & 5 & & 0.91 \\
\hline & & 10 & & 0.99 & & & 10 & & 0.92 \\
\hline & & 30 & & 0.95 & & & 30 & & 0.88 \\
\hline & & 50 & & 0.55 & & & 50 & & 0.93 \\
\hline & & 70 & & 0.19 & & & 70 & & 0.50 \\
\hline & & 90 & & 0.11 & & & 90 & & 0.25 \\
\hline & & 100 & & 0.09 & & & 100 & & 0.21 \\
\hline & 10000 & 0 & 6.14 & 1.00 & & 10000 & 0 & 1.54 & 1.00 \\
\hline & & 5 & & 0.99 & & & 5 & & 0.85 \\
\hline & & 10 & & 0.99 & & & 10 & & 1.03 \\
\hline & & 30 & & 0.96 & & & 30 & & 0.88 \\
\hline & & 50 & & 0.56 & & & 50 & & 0.83 \\
\hline & & 70 & & 0.17 & & & 70 & & 0.40 \\
\hline & & 90 & & 0.09 & & & 90 & & 0.40 \\
\hline & & 100 & & 0.09 & & & 100 & & 0.29 \\
\hline & 25000 & 0 & 4.52 & 1.00 & & 25000 & 0 & 1.41 & 1.00 \\
\hline & & 5 & & 0.89 & & & 5 & & 0.77 \\
\hline & & 10 & & 0.97 & & & 10 & & 1.00 \\
\hline & & 30 & & 0.96 & & & 30 & & 0.89 \\
\hline & & 50 & & 0.86 & & & 50 & & 0.61 \\
\hline & & 70 & & 0.51 & & & 70 & & 0.50 \\
\hline & & 90 & & 0.17 & & & 90 & & 0.44 \\
\hline & & 100 & & 0.13 & & & 100 & & 0.36 \\
\hline & 50000 & 0 & 4.60 & 1.00 & & 50000 & 0 & 1.76 & 1.00 \\
\hline & & 5 & & 0.96 & & & 5 & & 0.92 \\
\hline & & 10 & & 0.94 & & & 10 & & 1.01 \\
\hline & & 30 & & 0.89 & & & 30 & & 0.95 \\
\hline & & 50 & & 0.89 & & & 50 & & 0.97 \\
\hline & & 70 & & 0.65 & & & 70 & & 0.88 \\
\hline & & 90 & & 0.23 & & & 90 & & 0.79 \\
\hline & & 100 & & 0.18 & & & 100 & & 0.56 \\
\hline & 100000 & 0 & 3.15 & 1.00 & & 100000 & 0 & 2.09 & 1.00 \\
\hline & & 5 & & 0.97 & & & 5 & & 0.91 \\
\hline & & 10 & & 0.94 & & & 10 & & 0.86 \\
\hline & & 30 & & 0.90 & & & 30 & & 0.82 \\
\hline & & 50 & & 0.89 & & & 50 & & 0.83 \\
\hline & & 70 & & 0.66 & & & 70 & & 0.74 \\
\hline & & 90 & & 0.36 & & & 90 & & 0.58 \\
\hline & & 100 & & 0.25 & & & 100 & & 0.55 \\
\hline \multirow[t]{16}{*}{ COLO 201} & 7500 & 0 & 2.13 & 1.00 & Lu-134-A-H & 7500 & 0 & 2.39 & 1.00 \\
\hline & & 5 & & 0.83 & & & 5 & & 0.76 \\
\hline & & 10 & & 0.75 & & & 10 & & 0.70 \\
\hline & & 30 & & 0.59 & & & 30 & & 0.60 \\
\hline & & 50 & & 0.69 & & & 50 & & 0.42 \\
\hline & & 70 & & 0.41 & & & 70 & & 0.45 \\
\hline & & 90 & & 0.21 & & & 90 & & 0.42 \\
\hline & & 100 & & 0.12 & & & 100 & & 0.32 \\
\hline & 10000 & 0 & 2.14 & 1.00 & & 10000 & 0 & 1.86 & 1.00 \\
\hline & & 5 & & 0.96 & & & 5 & & 0.73 \\
\hline & & 10 & & 0.94 & & & 10 & & 0.45 \\
\hline & & 30 & & 0.68 & & & 30 & & 0.50 \\
\hline & & 50 & & 0.60 & & & 50 & & 0.32 \\
\hline & & 70 & & 0.35 & & & 70 & & 0.21 \\
\hline & & 90 & & 0.45 & & & 90 & & 0.22 \\
\hline & & 100 & & 0.48 & & & 100 & & 0.22 \\
\hline
\end{tabular}


Table 1. (Continued)

\begin{tabular}{|c|c|c|c|c|c|c|c|c|c|}
\hline Cell & $\begin{array}{c}\text { Number of } \\
\text { cells }(\text { cells } / \mathrm{ml})\end{array}$ & $\begin{array}{l}\text { Vitex conc. } \\
\qquad(\mu \mathrm{g} / \mathrm{ml})\end{array}$ & $\begin{array}{l}\text { Growth } \\
\text { rate }\end{array}$ & $\begin{array}{c}\text { Relative } \\
\text { growth rate }\end{array}$ & Cell & $\begin{array}{c}\text { Number of } \\
\text { cells }(\text { cells } / \mathrm{ml})\end{array}$ & $\begin{array}{l}\text { Vitex conc. } \\
\qquad(\mu \mathrm{g} / \mathrm{ml})\end{array}$ & $\begin{array}{l}\text { Growth } \\
\text { rate }\end{array}$ & $\begin{array}{l}\text { Relative } \\
\text { growth rate }\end{array}$ \\
\hline \multirow{8}{*}{\multicolumn{2}{|c|}{25000}} & 0 & 1.60 & 1.00 & & 25000 & 0 & 1.50 & 1.00 \\
\hline & & 5 & & 0.96 & & & 5 & & 0.86 \\
\hline & & 10 & & 0.98 & & & 10 & & 0.86 \\
\hline & & 30 & & 0.90 & & & 30 & & 0.72 \\
\hline & & 50 & & 0.80 & & & 50 & & 0.82 \\
\hline & & 70 & & 0.72 & & & 70 & & 0.47 \\
\hline & & 90 & & 0.70 & & & 90 & & 0.51 \\
\hline & & 100 & & 0.57 & & & 100 & & 0.35 \\
\hline \multirow{8}{*}{\multicolumn{2}{|c|}{50000}} & 0 & 2.72 & 1.00 & & 50000 & 0 & 2.29 & 1.00 \\
\hline & & 5 & & 0.84 & & & 5 & & 0.94 \\
\hline & & 10 & & 0.90 & & & 10 & & 0.91 \\
\hline & & 30 & & 0.70 & & & 30 & & 0.90 \\
\hline & & 50 & & 0.72 & & & 50 & & 0.79 \\
\hline & & 70 & & 0.51 & & & 70 & & 0.72 \\
\hline & & 90 & & 0.48 & & & 90 & & 0.57 \\
\hline & & 100 & & 0.41 & & & 100 & & 0.42 \\
\hline \multirow{8}{*}{\multicolumn{2}{|c|}{100000}} & 0 & 1.39 & 1.00 & & 100000 & 0 & 2.53 & 1.00 \\
\hline & & 5 & & 0.94 & & & 5 & & 0.94 \\
\hline & & 10 & & 0.89 & & & 10 & & 0.88 \\
\hline & & 30 & & 0.94 & & & 30 & & 0.80 \\
\hline & & 50 & & 0.62 & & & 50 & & 0.71 \\
\hline & & 70 & & 0.73 & & & 70 & & 0.42 \\
\hline & & 90 & & 0.65 & & & 90 & & 0.22 \\
\hline & & 100 & & 0.48 & & & 100 & & 0.30 \\
\hline
\end{tabular}

Cells (HCF and HE-21, MCF-7 and SKG-3a, SKOV-3 and KATO-III, COLO 201 and Lu-134-A-H) in the logarithmic growth phase were treated with various concentrations of Vitex extract for $48 \mathrm{~h}$. The number of cells means the initial cell density in the culture. Growth rate was estimated from the cell density of the controls cultivated for $24 \mathrm{~h}$ and that cultivated further for $48 \mathrm{~h}$, and the relative growth rate was calculated by dividing the growth rate of Vitex extract-treated cells at respective concentrations of the extract by the growth rate of control cells. Each value represents the mean of four measurements.

method.

Inductions of HO-1 Protein and Caspase Cascade in Presence to Oxidative Stress We first examined mRNA expression in Vitex extract-treated KATO-III cells using the RT-PCR technique to detect 23 genes: $\beta$-actin, bcl-2, Cox-2, Fas, Fas L, tumor necrosis factor (TNF)- $\alpha$, tumor necrosis factor receptor (TNFR)1, TNFR2, NF- $\kappa$ B, p53, Mn-superoxide dismutase (Mn-SOD), $\mathrm{Cu} / \mathrm{Zn}-\mathrm{SOD}$, thioredoxin (TXN), thioredoxin reductase (TXNRD), catalase, HO-1, glutathione peroxidase 1, glutathione $\mathrm{S}$-transferase, glutathione reductase, inducible nitric oxide synthase (iNOS), Cas-3, Cas-8, and Cas-9, according to the method described previously. ${ }^{12}$ ) A significant decrease in bcl-2 gene expression and an increase in TNF $\alpha, \mathrm{Cu} / \mathrm{Zn}-\mathrm{SOD}, \mathrm{HO}-1, \mathrm{TXN}$, and TXNRD were seen (data not shown). We then examined the protein expression of Mn-SOD, Cu/Zn-SOD, TXN, HO-1, Cas-3, Cas-8, and Cas-9 in Vitex-treated KATO-III cells with and without NAC by SDS-PAGE and Western blotting analysis. $\mathrm{Mn}-\mathrm{SOD}, \mathrm{Cu} / \mathrm{Zn}-\mathrm{SOD}$, and TXN proteins were expressed constitutively and no alteration in their expression was seen in the presence of $20 \mathrm{~mm}$ NAC (data not shown). Vitex extract-induced HO-1 protein expression importantly increased from $9 \mathrm{~h}$ after treatment, but was completely inhibited in the presence of $20 \mathrm{~mm}$ NAC (Fig. 5). Active forms of Cas-3 (18and $20-\mathrm{kDa}$ bands), Cas-8 (23- and 40-kDa bands), and Cas9 (37-kDa band) were found $12-24 \mathrm{~h}$ after treatment and increased with the treatment period, while pro-forms of Cas-3, -8 , and -9 (34-kDa, 55-kDa, and 46-kDa bands, respectively) decreased, corresponding to the active form increments. Furthermore, the increase in these active forms was suppressed or disappeared in the presence of $20 \mathrm{~mm}$ NAC.

\section{DISCUSSION}

We previously reported the cytotoxicity of Vitex extract in human cultured cell lines HCF, MCF-7, and SKOV-3. ${ }^{4}$ Using these three cell lines, we assumed that the cytotoxic activity of Vitex extract could be attributed to the growth activity of the respective cells. ${ }^{4)}$ Accordingly, we investigated the antitumor effects of Vitex extract in more detail in noncancerous HCF and HE-21 cells and in the cancer cell lines MCF-7, SKG-3a, SKOV-3, KATO-III, COLO 201, and Lu-134-A-H, as well as the mechanism of cell death due to Vitex extract.

In the logarithmic growth phase, eight types of cultured cells were treated for $48 \mathrm{~h}$ with Vitex extract, and then cell viability was measured. The results in Table 1 show that the growth rate depends on the initial cell density and that the cytotoxic effect of Vitex extract is dependent on the cell growth rate, except in the HE-21 cell line. These results suggest that the cytotoxicity may not be specific for cancer cell lines but attributed to the growth rate of the respective cell lines in the logarithmic growth phase. This was confirmed by the results of statistical analysis shown in Table 1 (see Figs. 1A, B). These cell lines were separated into two groups characterized by their growth activity. One group consists of HCF, MCF-7, SKG-3a, and SKOV-3, with relatively higher growth activity, and the other group of cell lines with a lower growth rates, i.e., KATO-III, COLO 201, and Lu-134-A-H. The growth rates of these cells and the Vitex extract cytotoxicity against them showed a considerably strong correlation in both cancerous and noncancerous cell lines. On the other hand, under confluent conditions (stationary phase) of cell growth, no Vitex extract concentration-dependent effect was seen, and the cytotoxic effect of Vitex extract was not as sig- 
(A)

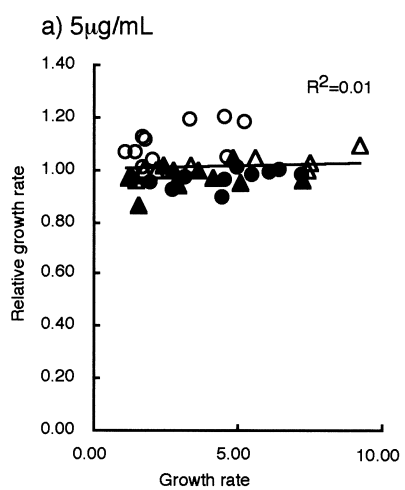

b) $10 \mu \mathrm{g} / \mathrm{mL}$
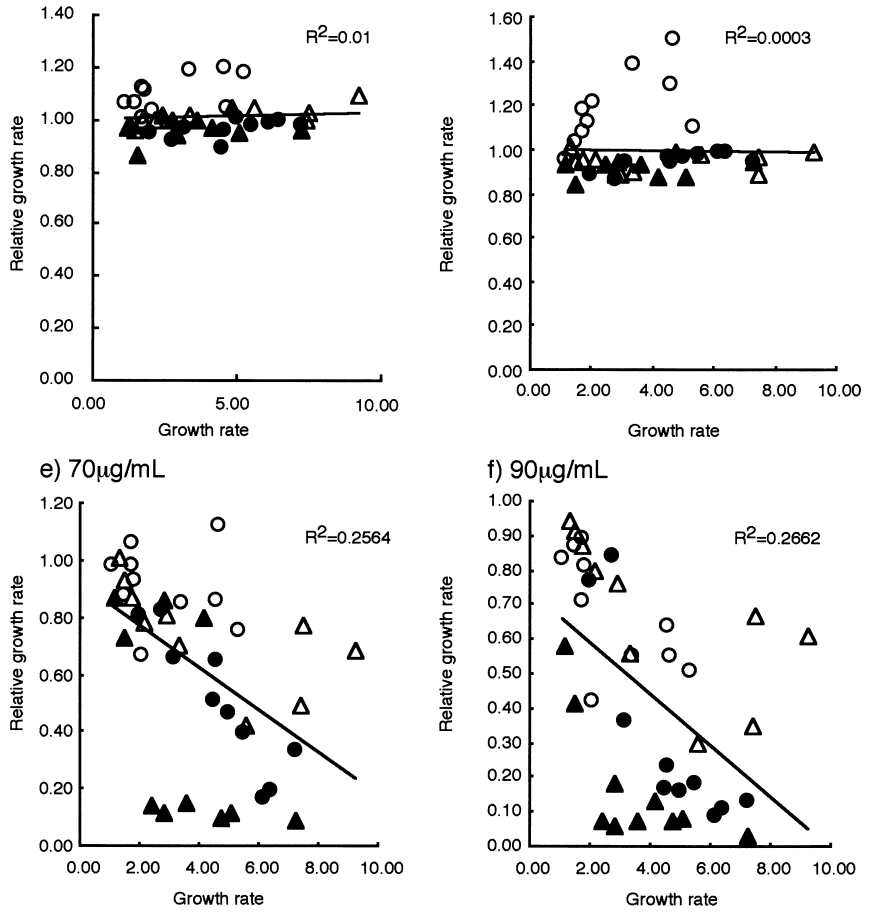

(B)
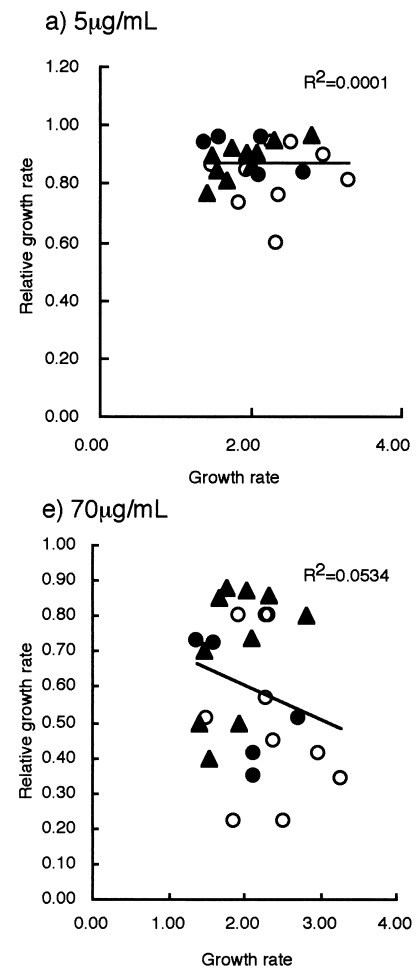

b) $10 \mu \mathrm{g} / \mathrm{mL}$
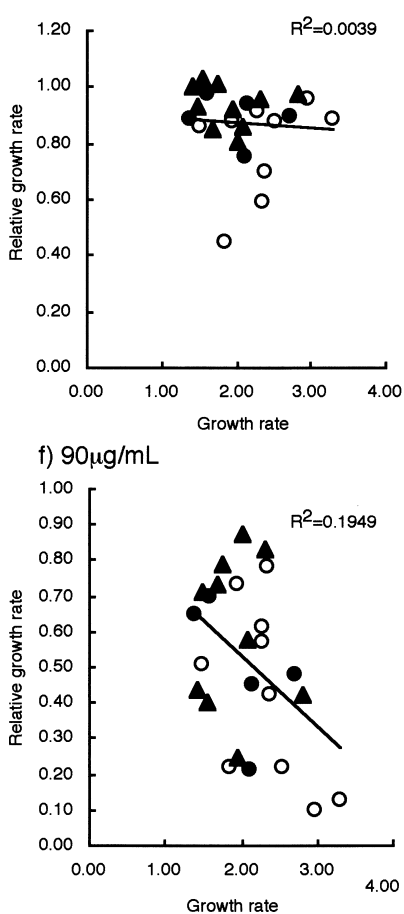

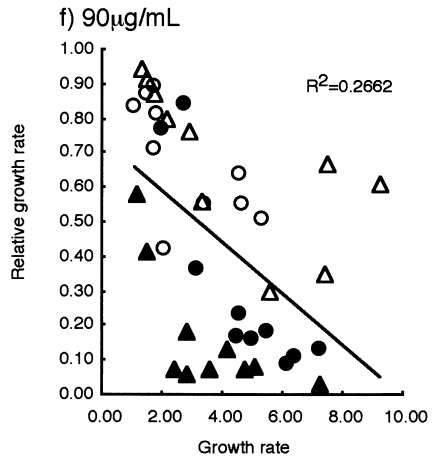

c) $30 \mu \mathrm{g} / \mathrm{mL}$

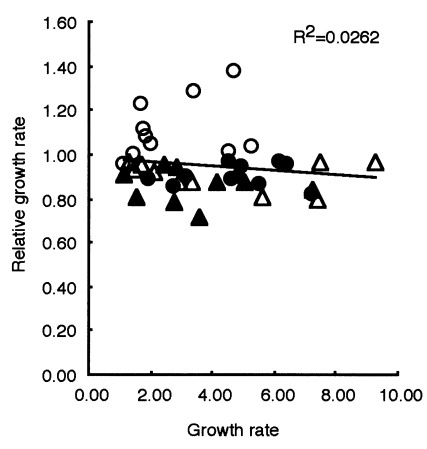

g) $100 \mu \mathrm{g} / \mathrm{mL}$

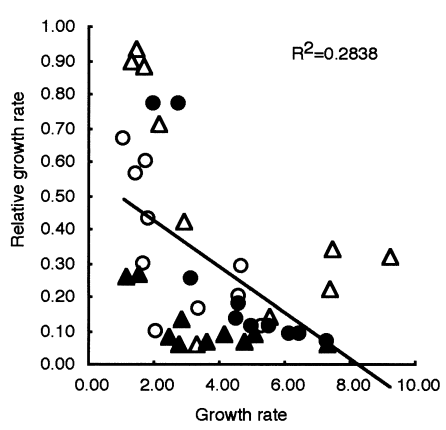

d) $50 \mu \mathrm{g} / \mathrm{mL}$

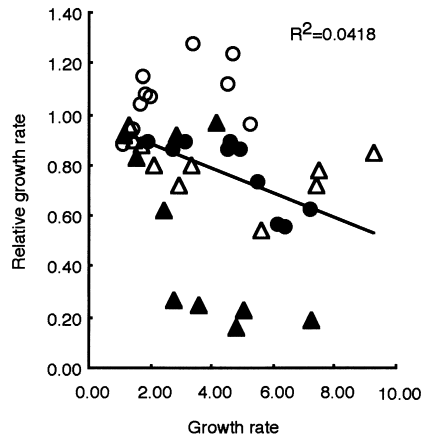

c) $30 \mu \mathrm{g} / \mathrm{mL}$

d) $50 \mu \mathrm{g} / \mathrm{mL}$
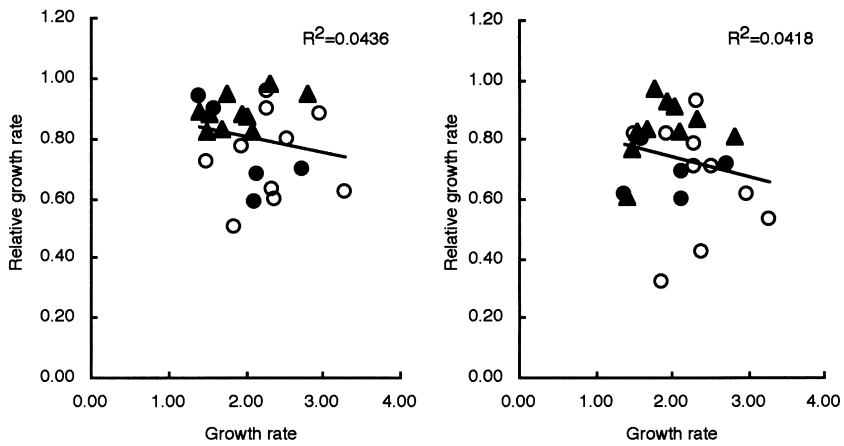

g) $100 \mu \mathrm{g} / \mathrm{mL}$

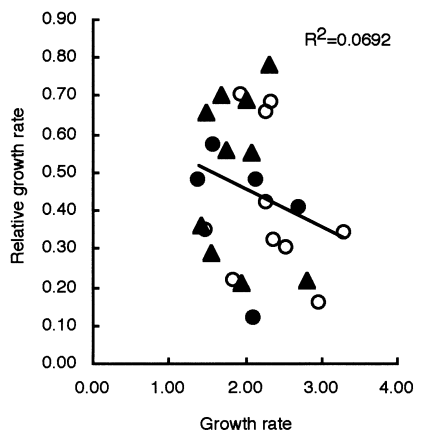

Fig. 1. Relationship between the Inhibition of Cell Growth and Growth Rate at Various Concentrations of Vitex Extract

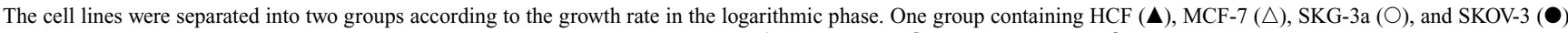
had a relatively higher growth rate (A), and the other group, which included KATO-III $(\mathbf{\Lambda})$, COLO $201(\bullet)$, and Lu-134-A-H (O), had a lower growth rate than those in the former group (B). The X-and Y-axis in each panel shows the growth rate and the relative growth rate, respectively, at various concentrations of Vitex extract. In each panel, a correlation curve with correlation coefficient and risk is shown as estimated by a T-test.

nificant (see Fig. 2). These results also suggest that the cytotoxicity of Vitex extract may be closely related to the growth activity of cells rather than to the specific difference between cancerous and noncancerous cells.
Hirobe et al. reported previously that the methanol extract of $V$. agnus-castus contained eight flavonoids and that seven of them had cytotoxic activity against mouse lymphocytic leukemia P388 cells. ${ }^{3)}$ Plant-derived polyphenolic com- 


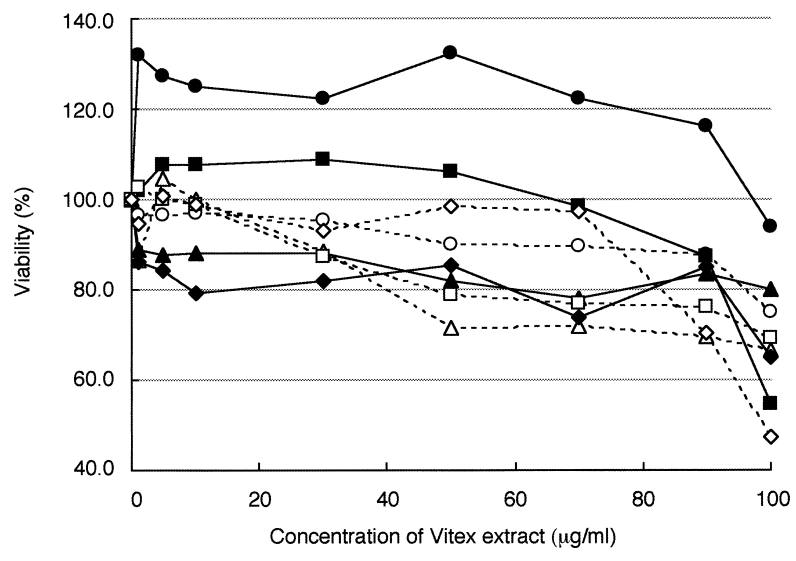

Fig. 2. Dose-Dependent Cytotoxic Activities of Vitex Extract against Human Cultured Cells in the Stationary Growth Phase

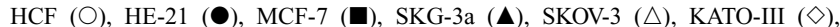
COLO $201(\square)$, and Lu-134-A-H $(\diamond)$ cells in the stationary growth phase were treated with various concentrations of Vitex extract. Relative viability of these cells was estimated by the XTT dye-reduction method. Each value represents the mean of four measurements.
(A) $\mathrm{HCF}$

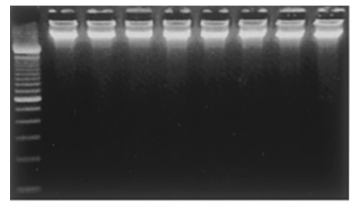

(B) HE-21

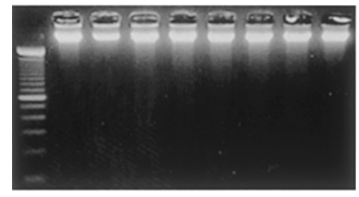

(C) MCF-7

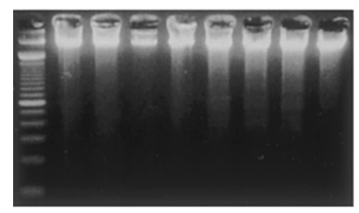

(D) SKG-3a

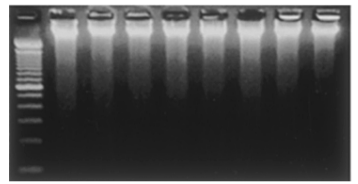

(St) $0 \quad 5 \quad 1030507090100$
(E) SKOV-3

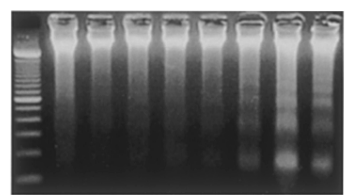

(F) KATO-III

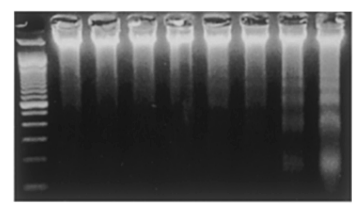

(G) COLO 201

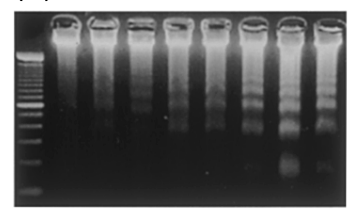

(H)Lu-134-A-H

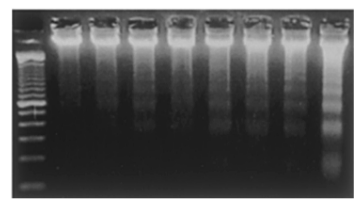

(St) $0 \quad 5 \quad 1030507090100$
Concentration of Vitex extract $(\mu \mathrm{g} / \mathrm{ml})$

Fig. 3. DNA Fragmentation Analysis of Vitex Extract-Treated Human Cultured Cells upon Agarose Gel Electrophoresis

Every cell line ((A) HCF, (B) HE-21, (C) MCF-7, (D) SKG-3a, (E) SKOV-3, (F) KATO-III, (G) COLO 201, and (H) Lu-134-A-H) in the late logarithmic growth phase was treated with various concentrations of Vitex extract for $48 \mathrm{~h}$, except that COLO 201 was treated for $24 \mathrm{~h}$. DNA fractions extracted from these cells $\left(1-2 \times 10^{6}\right.$ cells $)$ were analyzed by agarose gel electrophoresis in the presence of ethidium bromide.

pounds such as flavonoids have been implicated as antitumor compounds and to have apoptosis-inducing properties in cancer cells. ${ }^{13,14)}$ The cytotoxicity of Vitex extract against these cells may be attributed to these flavonoids. In this experi-

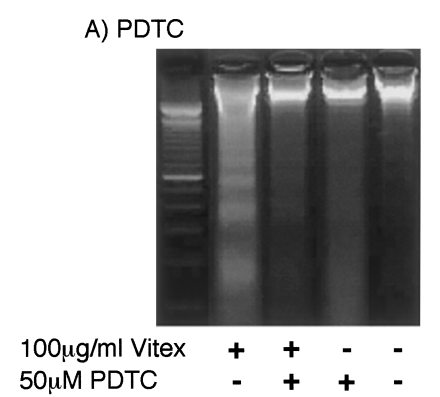

B) NAC

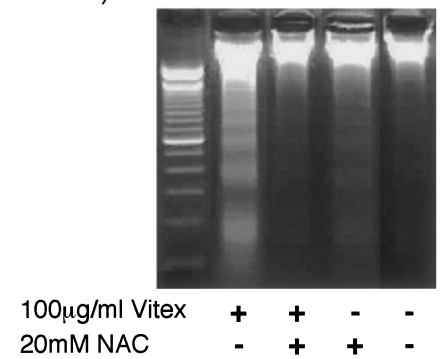

C) DNA fragmentation

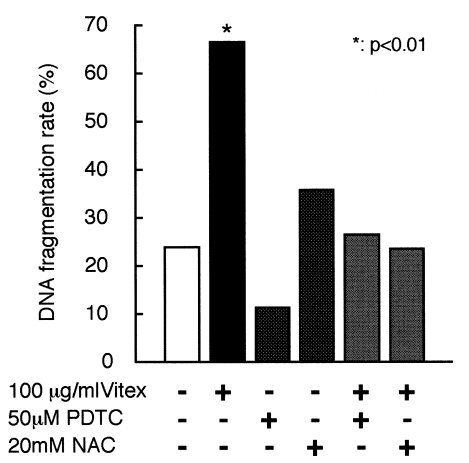

Fig. 4. Effect of the Antioxidative Reagents PDTC and NAC on DNA Fragmentation in Vitex Extract-Treated KATO-III Cells

KATO-III cells were cultivated for $48 \mathrm{~h}$ and treated with Vitex extract $100 \mu \mathrm{g} / \mathrm{ml}$ for $48 \mathrm{~h}$, with or without $0.05 \mathrm{~mm}$ PDTC (A) and $20 \mathrm{~mm}$ NAC (B). The control cell population was $1-2 \times 10^{6}$. The DNA fragmentation rates were calculated from data in (A) and (B) according to the method described previously ${ }^{12)}$ and shown in (C). Significant differences of each DNA fragmentation rate compared with that in controls was estimated using the T-test.

ment, we used a crude Vitex extract to investigate cytotoxic activity against human cancer cells, because Hirobe et al. also showed that the cytotoxic activity of the crude extract was significantly higher than that of any of the separated compounds (preliminary results). Phenomena like the cytotoxic effects of Vitex extract have often been observed when investigating biological activity in natural resources, and crude extracts of natural herbal medicines have been used empirically and generally. We must consider whether any other unknown components in Vitex extract play an important role in the cytotoxic effect.

The growth activity of cancer cells is known to be much higher than that of normal (noncancerous) cells in culture as well as in the human body, cancer cells are out of contact inhibition control, and antitumor agents generally show cytotoxicity against cells with higher growth activity by mechanisms such as the inhibition and/or suppression of increasing nucleic acid synthesis and metabolic pathways than in normal cells. From this point of view, it can be presumed that the cytotoxic active components contained in Vitex extract 


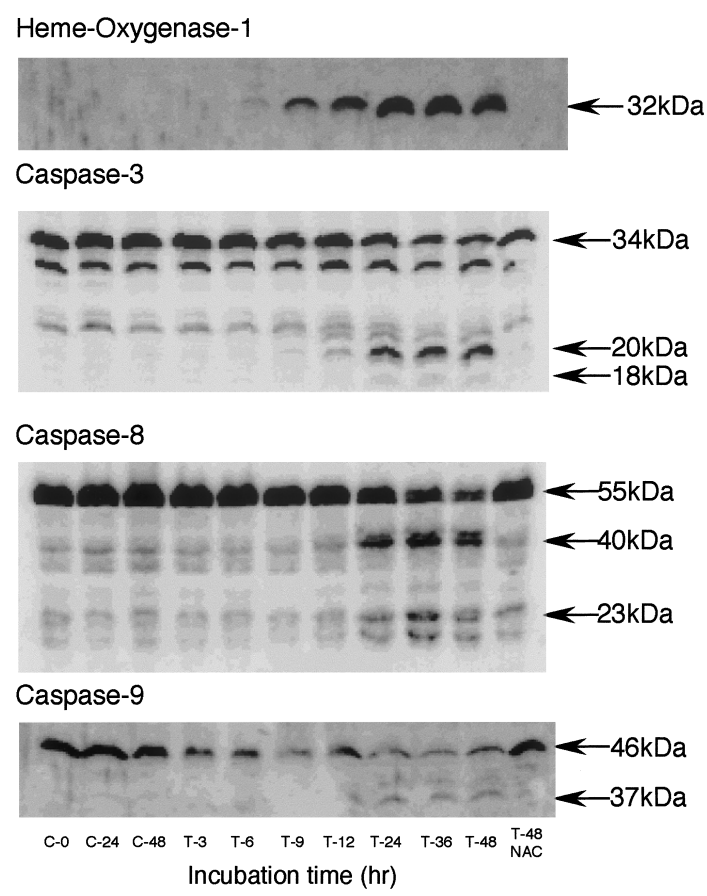

Fig. 5. Protein Expression of HO-1 Protein and Active Forms of Cas-3, -8, and -9 in Vitex Extract-Treated KATO-III Cells by SDS-PAGE and Western Blotting Analysis and Suppression by NAC

KATO-III cells in the log growth phase were treated with $100 \mu \mathrm{g} / \mathrm{ml}$ of Vitex extract for $48 \mathrm{~h}$ and harvested at appropriate times $\left(1-2 \times 10^{6}\right.$ cells). $\mathrm{C}$ and T repressed control cells and treated cells, respectively, and the numbers are incubation periods (h). Arrows and numbers on the right side of each figure are the molecular weight of each band calculated from molecular weights of standard proteins.

may prefer cancer cells, so that they are applicable to clinical treatment with minimal adverse reactions against normal cells in the living body. Because the results in this paper were obtained in an in vitro system using cultured human cells, the antitumor effects cannot be directly extrapolated to the clinical application of Vitex extract.

Previous studies demonstrated that a wide range of antitumor agents including chemotherapeutic agents, hormones, and various biologicals induce apoptosis in malignant cells in vitro. ${ }^{15)}$ We also investigated Vitex extract to determine whether it induces apoptotic cell death in cancerous and noncancerous cells. DNA fragmentation analysis of Vitex extract-treated cells revealed that the fragmentation appeared in DNA derived from SKOV-3, KATO-III, COLO 201, and Lu134-A-H cells but not in DNA from HCF, HE-21, MCF-7, and SKG-3a cells (see Fig. 3). The biochemical phenomenon of apoptosis is characterized by DNA fragmentation. ${ }^{16)}$ Thus the results suggest that SKOV-3, KATO-III, COLO 201, and Lu-134-A-H cells die through apoptosis with Vitex extract treatment. It is interesting that these cell lines underwent apoptosis, except that SKOV-3 cells showed relatively lower growth activity than $\mathrm{HCF}, \mathrm{MCF}-7$, and SKG-3a cells. Cell death of $\mathrm{HCF}, \mathrm{MCF}-7$, and SKG-3a cells with relatively higher growth rates may take place through necrosis. We do not yet have useful data on why cell strains with relatively lower growth activity die through apoptosis. We suspect that apoptotic cell death might be induced in these higher-growth cells during necrotic cell death, although the apoptotic phenomena are overshadowed by more rapid progressive necrosis.
Our data showed that the apoptotic DNA fragmentation of KATO-III cells was inhibited by the presence of the antioxidant reagents PDTC or NAC (see Fig. 4). It is now clear that lower concentrations of reactive oxygen species (ROS) including nitrogen intermediates can induce apoptosis in various cells. ${ }^{17)}$ If these oxidants can induce apoptosis, then antioxidants should be able to inhibit apoptosis. Dithiocarbamates, including PDTC, exert antioxidant effects in cells by eliminating hydrogen peroxide, scavenging the superoxide radical, ${ }^{18,19)}$ peroxynitrite, and the hydroxyl radical, ${ }^{20)}$ and blocking nuclear factor (NF)- $\kappa \mathrm{B}$ activation. ${ }^{21)}$ It has recently been demonstrated that PDTC acts as an oxidizing agent rather than as an antioxidant through the inhibition of $\mathrm{NF}-\kappa \mathrm{B}$ activation. ${ }^{22)} \mathrm{NAC}$ is a thiol-containing antioxidant, acts as a nucleophile and as a precursor of reduced glutathione, ${ }^{23)}$ and protects U937 cells from TNF- $\alpha$ - and ricin-induced apoptosis by maintaining mitochondrial integrity and functions, ${ }^{24)}$ and by maintaining an intracellular reducing condition by acting as a thiol supplier. ${ }^{25}$ The ability of NAC to impair apoptosis seemed to indicate that oxidative alterations of specific subcellular components could strongly influence the apoptotic machinery. ${ }^{26)}$ As shown by our results that two anti-oxidants inhibited DNA fragmentation in KATO-III cells, it is suggested that their antioxidative effects may implicate apoptotic cell death inhibitory effects. While it is possible to conclude that the mechanism of these effects may be caused by their radical-scavenging activity, we consider that other influences may play a role.

When we examined mRNA expression in Vitex extracttreated KATO-III cells using the RT-PCR technique for 23 genes, a significant decrease in bcl-2 gene expression and an increase in TNF- $\alpha, \mathrm{Cu} / \mathrm{Zn}-\mathrm{SOD}, \mathrm{HO}-1, \mathrm{TXN}$, and TXNRD were seen (data not shown). Protein expression in Vitex extract treated KATO-III cells was investigated with Western blotting analysis, and significantly increases in HO-1 protein and active forms of Cas-3, -8 and -9 proteins occurred, which were inhibited in the presence of NAC.

$\mathrm{HO}-1$ is a $32-\mathrm{kDa}$ microsomal enzyme that catalyzes the conversion of heme to biliverdin, releasing iron and carbon monoxide. ${ }^{27)}$ In vitro studies in human renal proximal tubule cells demonstrated that hemin, an inducer of HO-1, significantly attenuated cisplatin induced apoptosis and necrosis. ${ }^{28)}$ Most of the morphological changes that are observed during the apoptotic process are caused by a set of cysteine proteases, in the caspase cascade, that are activated especially in apoptotic cells. ${ }^{29)}$ Cas- 8 is the key initiator caspase in the death receptor pathways. ${ }^{30)}$ Nonreceptor-mediated apoptosis occurs primarily via the cytochrome c-dependent assembly of an apoptotic protease-activating factor 1 (Apaf-1)/Cas-9-containing apoptosome complex. ${ }^{31)}$ Effector caspases such as Cas-3 are usually activated proteolytically by an upstream caspase such as Cas-8 and Cas-9. ${ }^{31)}$ It was reported previously that ROS production by transforming growth factor (TGF) $\beta 1$ in rat fetal hepatocytes induced apoptosis accompanying loss of mitochondrial transmembrane potential, release of cytochrome $\mathrm{c}$, and activation of the caspase cascade containing Cas-3, -8 , and $-9 .{ }^{32}$ )

The induction of HO-1 and the activation of Cas-3, -8 , and -9 in KATO-III cells by Vitex treatment indicates the possibility of an intracellular oxidative alteration in cells with Vitex extract, and supports the above suggestion based on the 
results with antioxidants. The translocation of cytochrome $\mathrm{c}$ from the mitochondria into the cytosol at an early stage of apoptosis is inhibited by overexpression of antiapoptotic Bcl2 or Bcl-xL protein. ${ }^{33)}$ Our preliminary results showing that bcl-2 mRNA expression in Vitex extract-treated KATO-III cells disappeared $6 \mathrm{~h}$ after treatment is consistent with previous report of Adams and Cory. We do not consider that HO-1 is the only protein involved in the induction of apoptosis, however. Our results suggest a possibility that an alteration of intracellular oxidation is one causative factor in apoptotic induction in KATO-III cells.

Recently, natural medicinal herbs with both antitumor and apoptosis-inducing properties have been described. The putative mechanism for these properties of plant-derived polyphenolic compounds involve mobilization of endogenous copper and consequent prooxidant action. ${ }^{13)}$ It has been reported that growth inhibition and apoptosis induction by Anemarrhena asphodelmoides Bunge are characterized by the release of cytochrome $\mathrm{c}$ from the mitochondria, followed by an increase in Cas-3-like activity, ${ }^{34)}$ and that the structurally related flavonoids induce apoptosis in human leukemia HL-60 cells accompanying elevation of ROS production, loss of mitochondrial membrane potential, release of cytochrome $\mathrm{c}$ into the cytosol, and subsequent induction of pro-Cas 9 processing. ${ }^{35}$ ) These findings suggest that the redox state affects the regulation of apoptosis induced by natural herbal materials, and this is a possible mechanism of the cytotoxicity of Vitex extract.

\section{REFERENCES}

1) Hobbs C., "Vitex: The Women's Herbs," ed. by Miovic M., Botanica Press, CA, 1996.

2) Hirobe C., Palevitch D., Takeya K., Itokawa H., Nat. Med., 48, 168170 (1994).

3) Hirobe C., Qiao Z.-S., Takeya K., Itokawa H., Phytochemistry, 46, $521-524$ (1997).

4) Hirobe C., Ohyama K., Acta Obst. Gynaec. Jpn., 52, 1449-1456 (2000).

5) Kosano H., Takatani O., Cancer Res., 48, 6033-6036 (1988).

6) Sekiguchi M., Sakakibara K., Fujii G., Jpn. J. Exp. Med., 48, 61-68 (1978).

7) Ojima Y., Ito A., Nagase H., Mori Y., Biochim. Biophys. Acta, 1011, 61-66 (1989).

8) Scudiero D. A., Shoemaker R. H., Paull K. D., Monks A., Tierney S.,
Nofziger T. H., Currens M. J., Seniff D., Boyd M. R., Cancer Res., 48, 4827-4833 (1988).

9) Ohyama K., Emura A., Tamura H., Suga T., Bessho T., Oka K., Hirakawa S., Yamakawa T., Biol. Pharm. Bull., 21, 1024-1029 (1998).

10) Laemmli U. K., Nature (London), 227, 680-685 (1970).

11) Bradford M. M., Anal. Biochem., 72, 248-254 (1976).

12) Ohyama K., Yuan B., Bessho T., Yamakawa T., Eur. J. Biochem., 268, 6182-6189 (2001).

13) Hadi S. M., Asad S. F., Singh S., Ahmad A., TUBMB Life, 50, $167-$ 171 (2000).

14) Mukhtar H., Das M., Khan W. A., Wang Z. Y., Bik D. P., Bickers D. R., Cancer Res., 48, 2361-2365 (1988).

15) Kaufmann S. H., Earnshaw W. C., Exp. Cell Res., 256, $42-49$ (2000).

16) Wyllie A. H., Nature (London), 284, 555-556 (1980).

17) Payne C. M., Bernstein C., Bernstein H., Leuk. Lymphoma, 19, 43-93 (1995).

18) Mankhetkorn S., Abedinzadeh Z., Houee L.-C., Free Radic. Biol. Med., 17, 517-527 (1994).

19) Verhaegen S., McGowan A. J., Brophy A. R., Fernandes R. S., Cotter T. G., Biochem. Pharmacol., 50, $1021-1029$ (1995).

20) Liu J., Shigenaga M. K., Yan L. J., Mori A., Ames B. N., Free Radic. Res., 24, 461-472 (1996).

21) Bessho R., Matsubara K., Kubota M., Kuwakado K., Hirota H., Wakazono Y., Lin Y. W., Okuda A., Kawai M., Nishikomori R., Heike T., Biochem. Pharmacol., 48, 1883-1889 (1994).

22) Brennan P., O’Neill L. A., Biochem. J., 320, 975-981 (1996).

23) Cotgreave I. A., Adv. Pharmacol., 38, 205-227 (1997).

24) Cossarizza A., Franceschi C., Monti D., Salvioli S., Bellesia E., Rivabene R., Biondo L., Rainaldi G., Tinari A., Malorni W., Exp. Cell Res., 220, 232-240 (1995).

25) Oda T., Iwaoka J., Komatsu N., Muramatsu T., Biosci. Biotechnol. Biochem., 63, 341-348 (1999).

26) Malorni W., Rivabene R., Santini M. T., Donelli G., FEBS Lett., 327, $75-78$ (1993).

27) Choi A. M. K., Alam J., Am. J. Respir. Cell Mol. Biol., 15, 9-19 (1996).

28) Shiraishi F., Curtis L. M., Truong L., Poss K., Visner G. A., Madsen K., Nick H. S., Agarwal, A., Am. J. Physiol. Renal. Physiol., 278, F726-F736 (2000).

29) Hengartner M. O., Nature (London), 407, 770-776 (2000).

30) Krammer P. H., Nature (London), 407, 789-795 (2000).

31) Li P., Nijhawan D., Budihardjo I., Srinivasula S. M., Ahmad M., Alnemri E. S., Wang X., Cell, 91, 479_489 (1997).

32) Herrera B., Fernández M., Alvarez A. M., Roncero C., Benito M., Gil J., Fabregat I., Hepatology, 34, 549-556 (2001).

33) Adams J. M., Cory S., Science, 281, 1322-1326 (1998).

34) Takeda Y., Togashi H., Matsuo T., Shinzawa H., Takeda Y., Takahashi T., J. Gastroenterol., 36, 70-90 (2001).

35) Wang I. K., Lin-Shiau S. Y., Lin J. K., Eur. J. Cancer, 35, 1517-1525 (1999). 